\title{
PENGARUH TES OBJEKTIF TERHADAP HASIL BELAJAR FISIKA PESERTA DIDIK KELAS XI IPA SMA NEGERI 1 SIDENRENG RAPPANG
}

*Nur Mutiah

Universitas Negeri Makassar nurmutiah72gmail.com

Kaharuddin Arafah

Universitas Negeri Makassar eltigakahar@yahoo.com

Aisyah Azis

Universitas Negeri Makassar aisyahazisunm@gmail.com

*koresponden author
Abstrak - Penelitian ini bertujuan untuk mengetahui hasil belajar fisika peserta didik kelas XI IPA yang dinilai menggunakan tes objektif dan yang dinilai menggunakan tes subjektif. Selain itu, untuk mengetahui perbedaan hasil belajar fisika peserta didik kelas XI IPA SMA Negeri 1 Sidenreng Rappang yang dinilai menggunakan tes objektif dan tes subjektif. Penelitian ini merupakan penelitian eksperimen dengan menggunakan post- test only control groups design. Populasi penelitian ini adalah seluruh peserta didik kelas XI IPA SMA Negeri 1 Sidenreng Rappang tahun ajaran 2019/2020 yang berjumlah 179 dan sampel yang dipilih secara rambang. Analisis data hasil penelitian menggunakan teknik analisis deskriptif untuk mendeskripsikan hasil belajar fisika peserta didik dan teknik analisis inferensial untuk menguji hipotesis penelitian. Berdasarkan analisis deskriptif didapatkan bahwa rata-rata hasil belajar fisika peserta didik yang dinilai dengan menggunakan tes objektif 28, 89 dengan standar deviasi 9, 78 sedangkan rata-rata hasil belajar fisika peserta didik yang dinilai dengan menggunakan tes subjektif 31, 92 dengan standar deviasi 9,74. Hasil analisis inferensial menunjukkan bahwa tidak terdapat perbedaan yang signifikan hasil belajar fisika peserta didik yang dinilai dengan menggunakan tes objektif dan tes subjektif.

Kata Kunci : hasil belajar, tes objektif, tes subjektif.

Abstract - This research aims to see the physics learning result of class $11^{\text {th }}$ grade science students who are assessed using objective tests and subjective tests. In addition, to find out the differences in the physics learning result of of $11^{\text {th }}$ grade science students in SMA Negeri 1 Sidenreng Rappang which were assessed using objective tests and subjective tests. This research is an experimental with post-test only control groups design. The research population was all students of $11^{\text {th }}$ grade science students in SMA Negeri 1 Sidenreng Rappang on academic year 2019/2020 which amounted 179 and samples were randomly selected. Analysis of research data using descriptive analysis techniques to describe students physics learning result and inferential analysis techniques to test the research hypothesis. Based on the descriptive analysis, it was found that the average physics learning result of students using the objective test were 28.89 with a standard deviation of 9.78 while the average physics learning result of students using subjective tests were 31.92 with a standard deviation of 9.74. Inferential analysis shows that there is no significant difference in the physics learning result of students who are assessed using objective tests and subjective tests.

Keywords : learning result, objective test, subjective test. 


\section{A. PENDAHULUAN}

Pelaksanaan proses belajar mengajar dilakukan untuk mencapai hasil. Guru merupakan salah satu pihak yang bertanggung jawab terhadap hasil belajar yang diperoleh peserta didik. Guru sebagai fasilitator yang menyampaikan berbagai ilmu kepada peserta didiknya. Harapan guru adalah adanya perubahan tingkah laku yang lebih baik dari tidak tahu menjadi tahu dan dari tidak mengerti menjadi mengerti. Hasil dari proses belajar yang baik apabila peserta didik mengalami kemajuan.

Kompetensi hasil belajar mencakup ranah kognitif, ranah afektif, dan ranah psikomotor ditetapkan berdasarkan standar ketuntasan belajar bertujuan untuk memastikan sejauh mana tujuan pembelajaran dapat terlaksana dengan baik. Tujuan pembelajaran adalah pencapaian standar kompetensi maupun kompetensi dasar (Uno dan Satria, 2012). Sebagai guru, hendaknya senantiasa berupaya agar siswa mencapai keberhasilan belajar sesuai dengan kompetensi yang telah ditetapkan karena hal tersebut merupakan lambang keberhasilan guru dalam membelajarkan peserta didik. Untuk mengetahui apakah hasil proses belajar telah sesuai tujuan pembelajaran maka perlu dilakukan penilaian.

Penilaian dalam pembelajaran mempunyai hubungan erat dengan tujuan yang telah ditetapkan dalam kurikulum yang dapat digunakan sebagai alat oleh guru untuk mengetahui dan memahami tingkat keberhasilan peserta didik dalam menyerap materi yang diberikan dan sebagai bahan pertimbangan untuk menetapkan program pendidikan selanjutnya.

Penilaian hasil belajar dapat dilakukan dengan cara menggunakan alat ukur tes. Tes harus mempunyai mutu yang baik supaya dapat mencerminkan dengan tepat hasil belajar oleh masingmasing peserta didik. Tes yang diberikan dapat dilakukan dengan pemberian soal. Ada beberapa bentuk tes tertulis yaitu tes objektif dan subjetif, masing-masing bentuk memiliki keunggulan dan kelemahan.

Bentuk tes objektif dikenal dengan tes jawaban singkat yang terdiri dari tes pilihan ganda, tes isian, tes benar salah, dan tes menjodohkan yang menghendaki peserta didik untuk mengingat, menafsirkan, dan mengenali sehingga berkaitan dengan kemampuan belajar menggunakan otak kiri sedangkan bentuk tes subjektif dikenal dengan tes uraian yang menghendaki peserta didik untuk mengatur, menyatakan, dan menginterpretasi sehingga berkaitan dengan kemampuan belajar menggunakan otak kanan. Berdasarkan hasil tes yang diberikan, dapat diperoleh kesimpulan tentang perkembangan hasil belajar yang telah dicapai peserta didik setelah mengikuti proses belajar mengajar.

Observasi awal dan wawancara dengan guru pengampuh fisika di SMA Negeri 1 Sidenreng Rappang menunjukkan bahwa hasil belajar peserta didik kelas XI IPA masih sedang hingga rendah, data hasil belajar fisika peserta didik rata-rata 72 sementara standar ketuntasan belajar minimal (KBM) yang ditentukan oleh sekolah tersebut 75. Materi fisika yang diobservasi pada kelas XI IPA oleh peneliti adalah dinamika dan keseimbangan benda tegar. Berdasarkan ketuntasan hasil 
belajar kognitif, diketahui jumlah peserta didik yang tuntas tidak melebihi 50\% dari jumlah peserta didik secara keseluruhan. Adapun dari aspek afektif yang diamati diperoleh bahwa minat belajar peserta didik masih rendah. Hal ini dibuktikan kurangnya ketertarikan peserta didik dalam menerima, menanggapi dan terlibat aktif dalam pembelajaran.

Peserta didik memiliki kemampuan yang berbeda-beda dalam menyelesaikan soal yang diberikan. Penggunaan bentuk tes yang tepat harus memperhatikan kemampuan awal peserta didik, karena tidak semua peserta didik memiliki kemampuan yang sama, berbagai kemampuan yang teraktualisasikan beranjak dari otak. Setiap peserta didik mengalami dominasi otak yang berbeda dan mengkhususkan diri pada kemampuan-kemampuan tertentu. Selain itu, ketidakmampuan peserta didik menguasai tujuan pembelajaran diduga salah satu penyebab rendahnya hasil belajar. Dalam proses mengajar yang dilakukan, guru kadang-kadang tidak menyampaikan tujuan dan kompetensi yang akan dicapai. Menurut guru pengampuh mata pelajaran, tujuan pembelajaran itu telah terdapat pada buku yang digunakan peserta didik. Peserta didik sebaiknya diberitahu tujuan pembelajaran yang akan dicapai agar dapat memperkirakan urutan-urutan kegiatan pembelajaran yang diikutinya sehingga dapat memperkirakan soal ulangan dengan memahami tujuan pembelajaran. Masalah kegagalan peserta didik tidak hanya dari aspek hasil assessment belaka, ada berbagai faktor yang dapat menjadi penyebab salah satunya perumusan tujuan-tujuan itu sendiri tidak realistik (Hamalik, 2001).

Guru dalam memberikan tes belum sepenuhnya memenuhi syarat-syarat penyusunan soal yang baik dan benar. Menjelang pelaksanaan ujian guru sering direpotkan untuk menyusun butir tes. Hal ini disebabkan oleh belum tersedianya bank soal yang siap pakai, karena selama ini tes yang digunakan belum dianalisis secara seksama. Selain itu, Guru belum memvariasikan jenis pertanyaan yang diberikan kepada peserta didik. Hal-hal yang perlu diperhatikan agar konstruksi tes buatan guru lebih baik, yaitu dengan memvariasikan jenis pertanyaannya dalam bentuk (benar/salah, isian, pilihan ganda, mencocokkan, tes usai) (Basuki dan Hariyanto, 2014). Guru cenderung menggunakan alat ukur berupa tes subjektif dan belum pernah memberikan tes dalam bentuk objektif. Tes subjektif berkaitan dengan kemampuan belajar peserta didik menggunakan otak kanan yang berkaitan dengan kemampuan berpikir divergen dan tes objektif berkaitan dengan kemampuan belajar peserta didik menggunakan otak kiri yang berkaitan dengan dengan kemampuan berpikir konvergen. Jika fungsi belahan otak kanannya yang sering digunakan, anak akan lambat dalam berpikir logis, linier, dan teratur yang juga seringkali digunakan dalam kehidupan sehari-hari (Muhammad, 2010, h. 18). Guru perlu memberi kesempatan kepada peserta didik agar dapat menggunakan berbagai macam macam tes, sehingga kedua belahan otak kiri dan kanan dapat berkembang secara seimbang dan proporsional.

Fisika merupakan ilmu pengetahuan yang sistematis dan terstruktur yang memerlukan kemampuan penguasaan materi dasar sebagai pengetahuan prasyarat untuk menguasai materi dengan tingkat kesukaran yang lebih tinggi. Dengan pemberian bentuk tes objektif dan subjektif yang digunakan dalam penilaian hasil belajar telah mencakup enam jenjang ranah kognitif diharapkan dapat meningkatkan kemampuan peserta didik untuk memahami materi secara menyeluruh yang 
dapat meningkatkan hasil belajar peserta didik.

Berkenaan dengan analisis masalah diatas, maka sangat penting untuk dilakukan penelitian dengan tujuan untuk mengetahui hasil belajar fisika peserta didik kelas yang dinilai menggunakan tes objektif dan yang dinilai menggunakan dengan tes subjektif serta untuk mengetahui perbedaan hasil belajar fisika peserta didik kelas XI IPA SMA Negeri 1 Sidenreng Rappang yang dinilai menggunakan tes objektif dan yang dinilai menggunakan tes subjektif. Untuk itu peneliti mengadakan penelitian dengan judul "Pengaruh Tes Objektif Terhadap Hasil Belajar Fisika Peserta Didik Kelas XI IPA SMA Negeri 1 Sidenreng Rappang”.

1. Tes

Tes adalah suatu prosedur yang spesifik dan sistematis untuk mengukur tingkah laku seseorang, atau suatu pengukuran yang bersifat objektif mengenai tingkah laku seseorang, sehingga tingkah laku tersebut dapat digambarkan dengan bantuan angka, skala atau sistem kategori (Yusuf, 2015, h.92).

a. Bentuk-bentuk Tes

Bentuk tes dibedakan atas tes objektif dan subjektifi dimana tes tersebut memiliki penekanan tujuan yang berbeda dalam evaluasi hasil belajar.

1) Tes Objektif

Tes Objektif adalah suatu bentuk tes yang dalam penilaiannya tidak dipengaruhi oleh pribadi pemeriksa (Basuki dan Hariyanto, 2014, h. 39).Macam-macam tes objektif antara lain: (a) tes melengkapi, (b) Tes benar salah, (c) tes mencocokkan dan (d) tes pilihan ganda (Basuki dan Hariyanto. 2014). Berdasarkan beberapa macam dari tes objektif, dalam penelitian ini peneliti menggunakan tes pilihan ganda.

Tes bentuk pilihan ganda terdiri dari pokok soal (stem) dan pilihan jawaban (option). Pilihan jawaban terdiri atas kunci jawaban dan pengecoh (distractor) (Kusaeri, 2014, h.70).

Hal-hal yang perlu diperhatikan dalam menyusun tes pilihan ganda; jaminlah bahwa setiap pertanyaan terlihat jelas gagasan pokoknya, pilihan jawaban yang salah yang masuk akal, buatlah setiap opsi sama panjangnya, jangan ada yang terlalu panjang atau terlalu pendek, nyatakan secara jelas kepada peserta tes bahwa mereka harus memilih yang paling benar, dan bukan alternative jawaban benar (Basuki dan Hariyanto, 2014, h. 44).

2) Tes Subjektif/ Esai

Tes subjektif adalah suatu bentuk tes yang dalam penilaiannya dipengaruhi oleh pribadi pemeriksa yang disebut efek halo atau halo error. Efek halo adalah suatu bias kognitif dimana pertimbangan seseorang atau karakter seseorang dapat berpengaruh kepada seluruh kesan terhadap orang yang sedang diamati (Basuki dan Hariyanto, 2014, h.36).

Jenis-jenis tes esai dapat dibedakan menjadi dua bentuk; (a) tes esai bebas, tes ini membuka kesempatan kepada setiap pengikut tes untuk mengeluarkan pendapatnya sendiri sesuai dengan yang diketahui menurut pandangan masing-masing. (b)Tes esai terstruktur/ terbatas. Jenis tes ini lebih 
mengikat peserta ujian, tetapi lebih membantu pada sebagian orang lain dan juga pada waktu peskoran. Soal yang disusun tidak mengambang, tetapi lebih terarah dan terbatas (Yusuf, 2015, h. 208).

\section{b. Pola Pikir Otak}

Inti dari pendidikan adalah belajar, dan belajar dapat diartikan sebagai pemberian rangsangan agar otak kiri dan kanan bekerja secara seimbang serta menggunakan otak sesuai cara alamiahnya(Muhammad, 2010, h. 124).

Tabel 1 Fungsi-Fungsi Otak (Hemisfer)

\begin{tabular}{|c|c|}
\hline Otak kiri & Otak kanan \\
\hline $\begin{array}{l}\text { a. Berpikir kritis, logis, konvergen } \\
\text { b. Analitis } \\
\text { c. Lebih suka berbicara dan menulis } \\
\text { d. Memberi tanggapan pada instruksi dan } \\
\text { penjelasan verbal } \\
\text { e. Mengenali/mengingat nama } \\
\text { f. Mengendalikan bahasa dalam berpikir } \\
\text { dan mengingat } \\
\text { g. Memecahkan masalah dengan } \\
\text { menjadikan bagian-bagian lalu } \\
\text { mendekati masalah secara berurutan } \\
\text { dengan menggunakan logika } \\
\text { h. Keterampilan organisasi baik, rapi. } \\
\text { i. Suka stabilitas, bersedia mematuhi } \\
\text { peraturan } \\
\text { j. Sadar akan waktu dan jadwal } \\
\text { k. Aljabar merupakan matematika yang } \\
\text { lebih dipilih } \\
\text { l. Tidak terlalu baik dalam menafsirkan } \\
\text { bahasa tubuh } \\
\text { m. Mengendalikan emosi }\end{array}$ & $\begin{array}{l}\text { a. Berpikir untuk intuisi, divergen } \\
\text { b. Mensintesis } \\
\text { c. Lebih suka menggambar dan } \\
\text { memanipulasi objek } \\
\text { d. Memberi tanggapan pada instruksi dan } \\
\text { penjelasan tertulis } \\
\text { e. Mengenali dan mengingat wajah } \\
\text { f. Mengandalkan citra dalam berpikir dan } \\
\text { mengingat } \\
\text { g. Memecahkan masalah dengan mengkaji } \\
\text { seluruhnya konfigurasinya lalu mendekati } \\
\text { masalah melalui pola yang menggunakan } \\
\text { firasat } \\
\text { h. Berorganisasi tidak rapi } \\
\text { i. Suka perubahan, ketidakpastian } \\
\text { j. Kehilangan hubungan dengan waktu dan } \\
\text { jadwal } \\
\text { k. Geometri merupakan matematika yang } \\
\text { lebih disukai } \\
\text { 1. Bagus dalam menafsirkan bahasa tubuh } \\
\text { m. Bebas mengeluarkan emosi }\end{array}$ \\
\hline
\end{tabular}

(Bastable, 2002, h. 78).

Jangan anggap otak kanan lebih penting daripada otak kiri, begitu juga dengan otak kiri. Jangan juga pernah anggap sebagai belahan otak yang kurang penting keduanya mesti dikembangkan secara optimal. Jika sama-sama dikembangkan maka potensi yang didapatkan dari kemampuan kedua otak itu sangat positif bahkan, lebih meningkat daripada yang sewajarnya (Muhammad, 2010, h. 18).

Tes subjektif berkaitan dengan kemampuan belajar menggunakan otak kanan dan tes objektif berkaitan dengan kemampuan belajar menggunakan otak kiri. Setiap peserta didik mengalami dominasi otak yang berbeda, yang mana belahan otak bertanggung jawab terhadap cara berpikir yang berbeda-beda dan mengkhususkan diri pada kemampuan-kemampuan tertentu. Apabila peserta didik diberikan bentuk tes yang berbeda maka nantinya juga akan mengalami hasil belajar yang berbeda.

\section{Hasil belajar}

Hasil belajar merupakan wujud pencapaian peserta didik; sekaligus merupakan lambang keberhasilan pendidik dalam pembelajaran peserta didik (Yusuf, 2015, h. 181). 
Hasil belajar adalah sejumlah pengalaman yang diperoleh siswa yang mencakup ranah kognitif, afektif dan psikomotorik (Rusman, 2015, h. 67).

Hasil belajar fisika yang akan diselidiki pada penelitian ini adalah ranah kognitif dalam Taksonomi Bloom. Menurut Susetyo (2015), kompetensi hasil belajar teori Taksonomi Benjamin Bloom revisi Anderson, pada ranah (domain) kognitif meliputi mengingat, memahami, menerapkan, menganalisis, mengevaluasi dan berkreasi.

Berdasarkan kajian teori maka hipotesis penelitian ini adalah terdapat perbedaan yang signifikan hasil belajar fisika peserta didik XI IPA SMA Negeri 1 Sidenreng Rappang yang dinilai menggunakan tes objektif dengan yang dinilai menggunakan tes subjektif.

\section{B. METODE}

Penelitian ini merupakan penelitian eksperimen dengan desain penelitian post- test only control groups design. Penelitian dilaksanakan di SMA Negeri 1 Sidenreng Rappang Jalan Kartini No.1 kecamatan Panca Rijang, kabupaten Sidenreng Rappang. Penelitian dilaksanakan pada tanggal 18 Februari 2020 sampai dengan 15 Mei 2020 semester genap tahun ajaran 2019/2020.

Populasi penelitian ini adalah seluruh peserta didik kelas XI IPA SMA Negeri 1 Sidenreng Rappang yang berjumlah 179 peserta didik. Sampel yang diambil dalam penelitian ini terdiri dari kelas eksperimen yaitu kelas XI IPA 6 berjumlah 28 orang, dan kelas kontrol yaitu XI IPA 5 berjumlah 28 orang sehingga ukuran sampel sebesar 56 orang. Sampel dipilih secara rambang yakni rambang kelas.

Pelaksanaan penelitian pada tahap persiapan yakni: a) mengadakan observasi awal di SMA Negeri 1 Sidenreng Rappang dan wawancara dengan guru bidang studi fisika, b) membuat perangkat pembelajaran dan kisi-kisi, c) validasi instrumen tes hasil belajar kognitif peserta didik melalui ahli, d) mengurus surat izin penelitian, dan e) uji coba instrumen pada kelas dan analisis hasil uji coba instrumen. Tahap pelaksanaan yakni: a) mengajar pada masing-masing kelas sampel dan setiap berakhirnya pembelajaran masing-masing kelas sampel diberikan tes dengan bentuk soal yang berbeda. Untuk kelas eksperimen diberikan soal pilihan ganda berjumlah 5 butir, untuk kelas kontrol diberikan soal uraian berjumlah 1 butir, b) dilakukan post test untuk kedua kelompok dengan menggunakan tes yang sama yang terdiri dari tes pilihan ganda dan uraian dilakukan pada jam pelajaran fisika. Tahap akhir dilakukan analisis data secara deskriptif dan inferensial. Dan dilakukan penyusunan laporan skripsi.

Instrumen dalam penelitian ini yakni instrumen tes. Tes terdiri atas sekumpulan pertanyaan-pernyataan pada materi gelombang bunyi dan cahaya dan alat optik. Adapun bentuk tes yang digunakan antara lain tes objektif berupa pilihan ganda dan tes subjektif. 
Untuk mengetahui kelayakan instrumen yang telah disusun, maka dilakukan analisis kelayakan instrumen secara teoretis meliputi validasi melalui pakar menggunakan uji gregory oleh dua orang ahli pada bidangnya untuk memeriksa bahasa, keteraturan dan kesesuaian tiap item dengan kisi-kisi instrumen dengan persamaan

$$
r=\left[\frac{D}{A+B+C+D}\right]
$$

Keterangan:

$\mathrm{A}=$ banyaknya butir dalam sel A (relevansi lemah-lemah)

$\mathrm{B}=$ banyaknya butir dalam sel B (relevansi kuat-lemah)

$\mathrm{C}=$ banyaknya butir dalam sel C (relevansi lemah-kuat)

$\mathrm{D}=$ banyaknya butir dalam sel D (relevansi kuat-kuat)

Syarat uji coba Gregory, jika $r \geq 0,75$ atau $\geq 75 \%$ maka dapat dinyatakan layak untuk diujicobakan/digunakan

( Susetyo, 2015, h. 121-122)

Hasil kesepakatan antar penilai yang dilakukan oleh dua orang ahli diperoleh 66 item dengan relevansi $\mathrm{D}$ dan 5 item dengan relevansi $\mathrm{B}$, diperoleh validitas isi $\mathrm{r}=0,93$ dan instrumen layak untuk diuji cobakan.

Uji coba instrumen dilakukan pada kelas XI IPA 2 dan XI IPA 4 dengan total responden 64 peserta didik. Data yang diperoleh dari uji coba instrumen dianalisis secara empirik meliputi analisis butir secara kuantitatif dan menghitung validitas dan reliabilitas setiap butir.

Analisis butir secara kuantitatif dengan mencari tingkat kesukaran dan daya pembeda tiap item. Perhitungan tingkat kesukaran tiap item soal objektif dengan menggunakan persamaan sebagai berikut:

$$
p_{i}=\frac{\sum \mathrm{f}}{\mathrm{M}}
$$

Keterangan:

$\mathrm{p}_{\mathrm{i}} \quad=$ tingkat kesukaran butir ke-i

$\sum \mathrm{f} \quad=$ jumlah siswa yang menjawab benar

$\mathrm{M} \quad$ = jumlah peserta

(Susetyo, 2015, h. 185)

Berdasarkan kategori tingkat kesukaran tiap butir diperoleh dari analisis data yakni butir dengan kategori sukar 12 item, kategori sedang 35 butir dan kategori mudah 10 butir.

Soal bentuk uraian, indeks kesukaran dihitung dengan menggunakan rumus seperti berikut:

$$
\text { indeks kesukaran }(\mathrm{p})=\frac{\text { mean }}{\text { skor maksimum yang ditetapkan }}
$$

(Ali, Khaeruddin, 2012, h.91)

Berdasarkan kategori tingkat kesukaran tiap butir untuk soal uraian diperoleh dari analisis data yakni butir dengan kategori sukar 2 item, kategori sedang 8 butir dan kategori mudah 4 butir. 
Daya beda butir tes dilakukan karena setiap individu memiliki perbedaan kemampuan sehingga butir tes yang dibuat juga harus dapat memberikan gambaran adanya perbedaan, analisis daya beda untuk tes objektif menggunakan rumus :

$$
\mathrm{D}_{\mathrm{i}}=\frac{\sum f_{T}}{M_{T}}-\frac{\sum f_{R}}{M_{R}}
$$

Keterangan:

$\mathrm{D}_{\mathrm{i}} \quad$ = Daya beda

$\Sigma \mathrm{f}_{\mathrm{Ti}} \quad=$ Jumlah yang menjawab benar butir tes ke-i untuk kelompok tinggi

$\Sigma \mathrm{f}_{\mathrm{Ri}} \quad=$ Jumlah yang menjawab benar butir tes ke-i untuk kelompok rendah

$\mathrm{M}_{\mathrm{T}} \quad=$ Jumlah seluruh peserta kelompok tinggi

$\mathrm{M}_{\mathrm{R}} \quad$ = Jumlah seluruh peserta kelompok rendah

mempunyai kemampuan rendah

( Susetyo, 2015, h. 194)

Berdasarkan kategori daya beda tiap butir diperoleh dari analisis data yakni 1 butir sangat baik, 25 butir baik, 8 butir cukup, 8 butir kurang dan 15 butir jelek.

Daya pembeda untuk tes subjektif dihitung dengan rumus :

$$
\mathrm{D}=\frac{\operatorname{Mean}_{\mathrm{A}}-\mathrm{Mean}_{\mathrm{B}}}{\text { Skor maksimum }}
$$

(Zulaiha, 2008, h. 28)

Diperoleh dari analisis data daya pembeda untuk soal uraian yakni 1 butir sangat baik, 13 butir baik.

Pengujian validitas pada tes objektif yang menggunakan persamaan:

$$
\mathrm{r}_{\mathrm{pbi}}=\frac{\mathrm{M}_{\mathrm{P}}-\mathrm{M}_{\mathrm{t}}}{\mathrm{S}_{\mathrm{t}}} \sqrt{\frac{\mathrm{p}}{\mathrm{q}}}
$$

\section{Keterangan:}

$r_{p} \quad=$ koefisien korelasi biserial

$M_{P} \quad$ = rerata skor dari subjek yang menjawab betul bagi item yang dicari validitasnya

$M_{t} \quad=$ rerata skor total

$S_{t} \quad=$ standar deviasi dari skor total

$p \quad=$ proporsi siswa yang menjawab benar

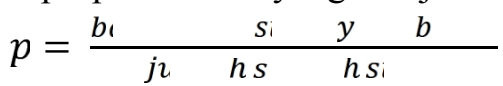

$q \quad=$ proporsi siswa yang menjawab salah $(\mathrm{q}=1-\mathrm{p})$

(Arikunto, 2009, h. 79)

Hasil analisis validitas butir tes objektif diperoleh $r_{\text {tabel }} 0,25$ pada taraf signifikansi 0,05 , Jika $r_{p}>r_{\text {tabel }}$ butir dinyatakan valid. Dari 57 butir yang diuji cobakan didapatkan 36 butir dalam kategori valid dan 21 butir dalam kategori tidak valid.

Pengujian validitas pada tes subjektif yang menggunakan persamaan:

$$
r_{\text {hit }}=\frac{n\left(\sum X\right)-\left(\sum X\right)\left(\sum Y\right)}{\sqrt{\left\{n \sum X^{2}-\left(\sum X\right)^{2}\right\}}\left\{n \sum Y^{2}-\left(\sum Y\right)^{2}\right\}}
$$


Selanjutnya dihitung dengan uji-t dengan rumus :

$$
t_{\text {hi1 }}=\frac{r \sqrt{n-2}}{\sqrt{1-r^{2}}}
$$

Keterangan:

$$
\begin{array}{ll}
r_{\text {hit }} & =\text { koefisien korelasi } \\
\sum X & =\text { jumlah skor item } \\
\sum Y & =\text { jumlah skor total (seluruh item) } \\
\mathrm{n} & =\text { jumlah responden } \\
\mathrm{t} & =\text { nilai } \mathrm{t}_{\text {hitung }} \\
\mathrm{r} & =\text { koefisien korelasi hasil } r_{\text {hit }} \\
& \text { Untuk } \alpha=0,05 \text { dan derajat kebebasan } d=n-2 . \text { Dengan kaidah keputusan jika } t_{\text {hit }} \quad>
\end{array}
$$$$
t_{t} \text { maka data valid. Sebaliknya jika } t_{h i t}<t_{t} \text { maka tidak valid. }
$$

(Riduwan, 2010. h. 110)

Hasil analisis validitas butir tes subjektif diperoleh $t_{t} \quad=1,9993$ dari 14 butir yang diuji cobakan semua butir tersebut dinyatakan valid.

Selanjutnya dilakukan pengujian reliabilitas instrumen untuk tes objektif dengan menggunakan rumus Kuder Richardson (KR-20) sebagai berikut:

$$
\mathrm{r}_{i i}=\left[\frac{k}{k-1}\right]\left[\frac{s_{t}^{2}-\sum p_{i} q_{i}}{s_{t}^{2}}\right]
$$

Keterangan:

$$
\begin{array}{ll}
\mathrm{r}_{\mathrm{ii}} & =\text { reliabilitas tes secara keseluruhan } \\
\mathrm{k} & =\text { jumlah item dalam instrumen } \\
\mathrm{p}_{\mathrm{i}} & =\text { proporsi banyaknya subjek yang menjawab pada item } 1 \\
\mathrm{q}_{\mathrm{i}} & =1-\mathrm{p}_{\mathrm{i}} \\
\mathrm{s}_{\mathrm{t}} & =\text { varians total }
\end{array}
$$

(Sugiyono, 2017, h. 132)

Berdasarkan hasil analisis butir, diperoleh reliabilitas tes objektif sebesar sebesar $r_{i i}=0,83$.

Pengujian reliabilitas instrumen untuk tes subjektif dengan menggunakan rumus Alpha sebagai berikut:

$$
\mathrm{r}_{\mathrm{ii}}=\left(\frac{\mathrm{k}}{\mathrm{k}-1}\right)\left(1-\frac{\sum \mathrm{S}_{\mathrm{i}}}{\mathrm{S}_{\mathrm{t}}}\right)
$$

Keterangan:

$$
\begin{array}{ll}
\mathrm{r}_{11} & =\text { Nilai reabilitas } \\
\Sigma \mathrm{S}_{\mathrm{i}} & =\text { Jumlah varians skor tiap-tiap } \\
\mathrm{S}_{\mathrm{t}} & =\text { Varians total } \\
\mathrm{k} & =\text { Jumlah item }
\end{array}
$$

Keputusan dengan membandingkan $r_{i j}$ dengan $r_{\text {tabel }}$, dengan kaidah keputusan jika $r_{i j}>r_{t_{i}}$ berarti reliabel dan $r_{i j}<r_{t_{i}} \quad$ berarti tidak reliabel. 
Diperoleh $\mathrm{r}_{\mathrm{ij}}=1,15$ lebih besar dari $\mathrm{r}_{\mathrm{t}} \quad=0,25$ maka semua data yang dianalisis dengan metode Alpa adalah reliabel.

Butir-butir yang dinyatakan valid ditarik secara proporsional pada setiap indikator yang akan digunakan pada peserta didik yang merupakan sampel penelitian agar memenuhi validitas logik, sehingga diperoleh instrumen hasil belajar kognitif yang akan diujikan pada sampel terdiri dari 25 butir pilihan ganda dan 5 soal uraian/essai.

Data yang diperoleh dalam penelitian ini semuanya akan diolah dan dianalisis dengan menggunakan teknik statistik deskriptif dan statistik inferensial. Statistik deskriptif meliputi nilai terendah, nilai tertinggi, rata rata, standar deviasi dan varians yang dihitung menggunakan microsoft excel. Statistik inferensial meliputi uji dasar statistika yaitu uji normalitas dan uji homogenitas dan uji hipotesis.

Uji normalitas menggunakan persamaan Chi-Kuadrat.

$$
x^{2}=\sum_{1}^{k} \frac{\left(f_{o}-f_{e}\right)^{2}}{f_{e}}
$$

Keterangan:

$x^{2}=$ Nilai chi-kuadrat

$f_{o} \quad=$ frekuensi yang diobservasi (frekuensi empiris)

$f_{e} \quad=$ frekuensi yang diharapkan (frekuensi teoritis)

Kriteria pengujian data yang berasal dari populasi terdistribusi normal bila $x_{\text {hit }}^{2} \leq$ $x_{t}^{2} \quad$ dimana $x_{t}^{2} \quad$ diperoleh dari daftar $x^{2}$ dengan $d=(k-1)$ pada taraf signifikan $\alpha=0,05$.

(Riduwan, 2010, h. 130)

Uji homogenitas dengan menggunakan uji- F :

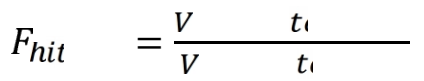

(Sudjana, 2005, h.250)

Kriteria pengujian apabila $F_{h i t} \geq F_{t}$ maka data tidak bersifat homogen. Sebaliknya jika $F_{\text {hit }} \leq F_{t}$ maka data bersifat homogen dengan derajat kebebasan $d$ pembilang $=$ $(n-1)$ dan $d$ penyebut $=(n-1)$ pada taraf signifikansi $\alpha=0,05$.

(Sudjana, 2005, h.250)

Pengujian hipotesis menggunakan uji dua pihak dengan uji-t sebagai berikut :

$$
t_{\text {hit }}=\frac{\overline{x_{1}}-\overline{x_{2}}}{s \sqrt{\frac{1}{n_{1}}+\frac{1}{n_{2}}}}
$$

Dimana :

$$
s^{2}=\frac{\left(n_{1}-1\right) s_{1}^{2}+\left(n_{2}-1\right) s_{2}^{2}}{n_{1}+n_{2}-2}
$$

Keterangan:

$\begin{array}{ll}\overline{\mathrm{x}_{1}} & \text { : skor rata-rata kelas eksperimen } \\ \overline{\mathrm{x}_{2}} & \text { : skor rata-rata kelas kontrol } \\ \mathrm{s} & : \text { standar deviasi }\end{array}$ 
$\mathrm{n}_{1} \quad$ : jumlah sampel kelas eksperimen

$\mathrm{n}_{2} \quad$ : jumlah sampel kelas kontrol

$\mathrm{s}^{2} \quad$ : varians

$\mathrm{s}_{1}{ }^{2} \quad$ : varians kelompok eksperimen

$\mathrm{s}_{2}{ }^{2} \quad$ : varians kelompok kontrol

Dengan kriteria penerimaan $H_{0}$ diterima jika $-t_{t} \leq t_{h i t} \leq+t_{t}$, dengan $d=$ $\left(n_{1}+n_{2}-2\right)$.

(Sudjana, 2005, h.239)

\section{HASIL DAN PEMBAHASAN}

Hasil analisis deskriptif untuk mendeskripsikan karakteristik distribusi skor hasil belajar fisika peserta didik. Berikut disajikan skor hasil belajar peserta didik untuk kedua kelas.

Tabel 2. Skor Statistik Deskriptif Hasil Belajar Fisika Peserta Didik Kelas Eksperimen dan Kontrol

\begin{tabular}{lcc}
\hline \multirow{2}{*}{ Statistik } & \multicolumn{2}{c}{ Hasil Belajar } \\
\cline { 2 - 3 } & Eksperimen & Kontrol \\
\hline Skor ideal maksimum & 50 & 50 \\
Skor ideal minimum & 1 & 1 \\
Jumlah butir soal & 30 & 30 \\
Ukuran sampel & 28 & 28 \\
Skor tertinggi & 43 & 44 \\
Skor terendah & 4 & 6 \\
Skor rata-rata & 28,89 & 31,92 \\
Standar deviasi & 9,78 & 9,74 \\
Varians & 95,59 & 94,94 \\
\hline
\end{tabular}

Tabel 2 menunjukkan bahwa skor tertinggi yang dicapai pada kelas eksperimen adalah 43 dan kelas kontrol adalah 44 dari skor ideal maksimum apabila semua soal benar dan skor terendah yang dicapai pada kelas eksperimen adalah 4 dan kelas kontrol adalah 6 apabila semua soal pilihan ganda dijawab salah, sedangkan skor rata-rata yang dicapai untuk kelas eksperimen adalah 28, 89 dengan standar deviasi 9,78 dan kelas kontrol adalah 31, 92 dengan standar deviasi 9, 74. Berdasarkan data tersebut terlihat bahwa kelas kontrol yang diberikan tes essai selama pembelajaran memiliki skor rata rata hasil belajar lebih tinggi daripada kelas eksperimen yang diberikan tes pilihan ganda.

Presentasi distirbusi skor hasil belajar fisika pada kelas eksperimen terlihat pada tabel berikut.

Tabel 3.Distribusi Frekuensi Kumulatif Skor Hasil Belajar Fisika Kelas Eksperimen

\begin{tabular}{|c|c|c|c|c|c|c|}
\hline \multirow{2}{*}{$\begin{array}{l}\text { Interval } \\
\text { Kelas }\end{array}$} & \multirow[t]{2}{*}{$f$} & \multirow[t]{2}{*}{$x_{i}$} & \multicolumn{2}{|c|}{$\begin{array}{c}\text { Kumulatif kurang } \\
\text { dari }\end{array}$} & \multicolumn{2}{|c|}{$\begin{array}{c}\text { Kumulatif lebih } \\
\text { dari }\end{array}$} \\
\hline & & & $\mathrm{Kf}$ & $\mathrm{K}(\%)$ & $\mathrm{Kf}$ & $\mathrm{K}(\%)$ \\
\hline $4-11$ & 1 & 7,5 & 1 & 3,57 & 28 & 100 \\
\hline $12-19$ & 5 & 15,5 & 6 & 21,43 & 27 & 96,43 \\
\hline $20-27$ & 3 & 23,5 & 9 & 32,14 & 22 & 78,57 \\
\hline $28-35$ & 13 & 31,5 & 22 & 78,57 & 19 & 67,86 \\
\hline
\end{tabular}


Gambaran persentase skor hasil belajar fisika peserta didik kelas eksperimen ditampilkan pada histogram berikut.

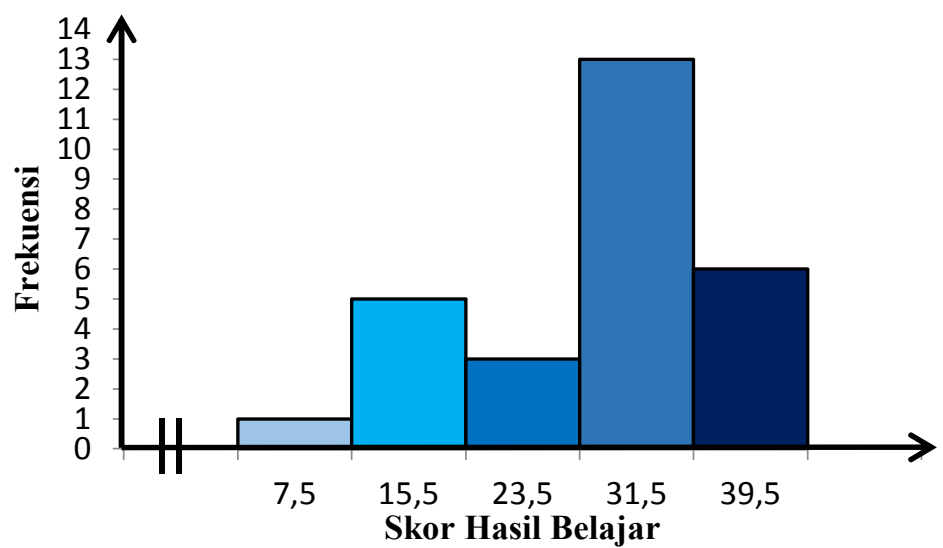

Gambar 1. Histogram Distribusi Frekuensi Skor Hasil Belajar Kelas Eksperimen

Tabel 3 dan gambar 1 diperoleh bahwa skor rata-rata hasil belajar peserta didik kelas eksperimen yaitu 28, 89 berada pada rentang skor 28 - 35 dengan jumlah peserta didik yang memperoleh skor diatas rata-rata adalah sebanyak 19 peserta didik.

Presentasi distribusi skor hasil belajar fisika peserta didik pada kelas kontrol terlihat pada tabel berikut.

Tabel 4. Distribusi Frekuensi Kumulatif Skor Hasil Belajar Fisika

\begin{tabular}{|c|c|c|c|c|c|c|}
\hline \multirow{2}{*}{$\begin{array}{c}\text { Interval } \\
\text { Kelas }\end{array}$} & $f$ & $x_{i}$ & $\frac{\mathrm{as}}{\mathrm{K}}$ & $\begin{array}{l}\text { ulatif } \\
\text { g dari }\end{array}$ & Kun & $\begin{array}{l}\text { tif lebih } \\
\text { ari }\end{array}$ \\
\hline & & & $\mathrm{Kf}$ & $\mathrm{K}(\%)$ & $\mathrm{Kf}$ & $\mathrm{K}(\%)$ \\
\hline $6-13$ & 2 & 9,5 & 2 & 7,14 & 28 & 100 \\
\hline $14-21$ & 2 & 17,5 & 4 & 14,29 & 26 & 92,86 \\
\hline $22-29$ & 6 & 25,5 & 10 & 35,71 & 24 & 85,71 \\
\hline $30-37$ & 7 & 33,5 & 17 & 60,71 & 18 & 64,29 \\
\hline $38-45$ & 11 & 41,5 & 28 & 100 & 11 & 39,29 \\
\hline
\end{tabular}

Adapun gambaran persentase skor hasil belajar fisika peserta didik kelas kontrol ditampilkan pada histogram berikut. 


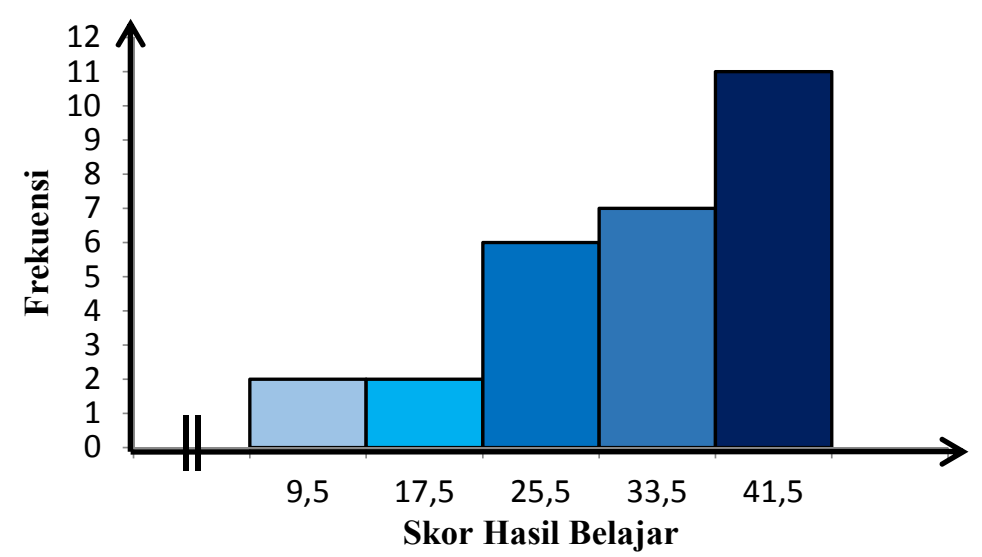

Gambar 2. Histogram Distribusi Frekuensi Skor Hasil Belajar Kelas Kontrol

Tabel 4 dan gambar 2 menunjukkan bahwa skor rata-rata yaitu 31, 92 berada pada rentang 30 - 37 dengan jumlah peserta didik yang memperoleh skor diatas rata-rata adalah sebanyak 16 peserta didik.

Jika skor tes hasil belajar fisika dikelompokkan kedalam lima kategori maka diperoleh diagram batang distribusi frekuensi dan persentase untuk kelas eksperimen dan kontrol sebagai berikut.

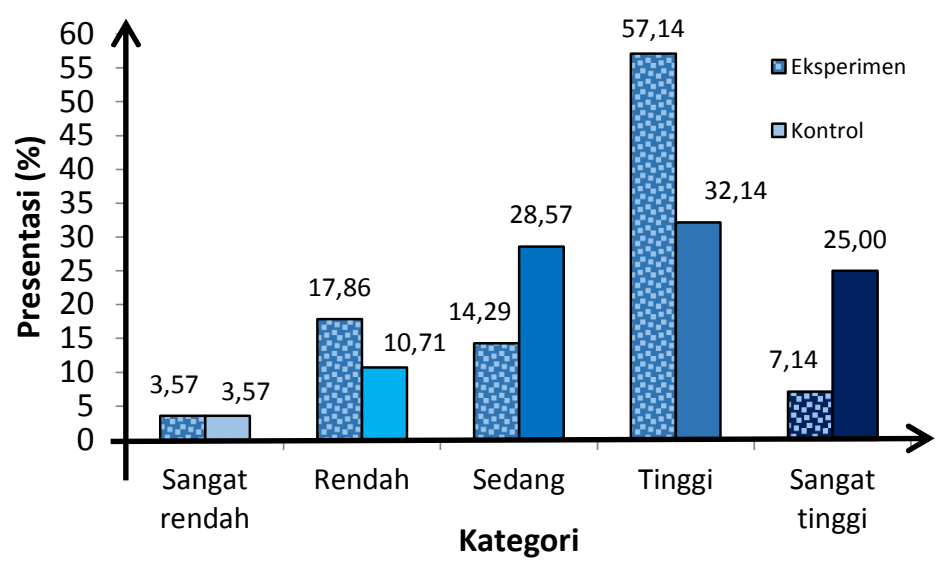

Gambar 3. Diagram Batang Skor Hasil Belajar Fisika Kelas Eksperimen dan Kelas Kontrol berdasarkan Distribusi Frekuensi

Gambar 3 diketahui bahwa hasil belajar fisika pada peserta didik kelas XI IPA SMA Negeri 1 Sidenreng Rappang pada kelas Eksperimen yang diberikan tes objektif selama pembelajaran paling banyak berada pada kategori tinggi dengan frekuensi 16 dan presentase 57,14 \% sedangkan kelas kontrol yang diberikan tes subjektif paling banyak berada pada kategori sangat tinggi dengan frekuensi 9 dan presentase 32,14\%. Grafik tertinggi pada kelas eksperimen yang dinilai menggunakan tes objektif dan kelas kontrol yang dinilai menggunakan tes subjektif yaitu pada kategori tinggi. Walaupun berada pada kategori yang sama namun jumlah frekuensi pada kategori tersebut jauh berbeda.

Hasil analisis inferensial bertujuan untuk menentukan ada tidaknya perbedaan yang signifikan hasil belajar fisika peserta didik yang dinilai menggunakan tes objektif dengan yang dinilai menggunakan tes subjektif. 
Berdasarkan hasil pengujian hipotesis penelitian dengan menggunakan uji dua pihak dengan uji-t diperoleh $t_{h i t}=-1,076$ sedangkan $t_{t_{i}}=2,006$ pada taraf signifikan $0,05 \mathrm{dan} \mathrm{dk}=54$. Berdasarkan analisis tersebut dapat dilihat bahwa nilai $t_{h i t} \quad$ untuk hasil belajar fisika berada pada rentang $-2,006 \leq-1,076 \leq+2,006$. Dengan demikian $H_{0}$ diterima dan $H_{1}$ ditolak sehingga dapat disimpulkan bahwa tidak ada perbedaan yang signifikan hasil belajar fisika peserta didik yang dinilai menggunakan tes objektif dan yang dinilai dengan menggunakan subjektif.

Tes hasil belajar merupakan tes yang digunakan untuk menilai hasil pelajaran yang telah diberikan selama proses pembelajaran. Diberikannya tes objektif dan subjektif untuk mengetahui hasil belajar manakah yang lebih baik untuk peserta didik dan untuk mengetahui perbedaan hasil belajar antara peserta didik yang dinilai dengan menggunakan tes objektif dan tes subjektif. Sehingga dapat memberikan manfaat bagi peneliti dan guru dalam memilih tes yang tepat bagi penggunaan tes hasil belajar.

Proses pembelajaran berangkat dari pandangan bahwa setiap individu memiliki kecerdasan dan kekuatan otak yang berbeda-beda. Setiap peserta didik mempunyai kecenderungan untuk menggunakan otak kiri atau otak kanan. Dengan perbedaan ini menuntut penanganan yang berbeda-beda sehingga mempengaruhi gaya belajar secara berbeda-beda.

Idealnya otak kiri dan otak kanan manusia haruslah seimbang supaya dapat menjadi orang yang cerdas. Jika sama-sama dikembangkan maka potensi yang didapatkan dari kemampuan kedua otak itu sangat positif bahkan, lebih meningkat daripada yang sewajarnya (Muhammad, 2010, h. 18).

Terkait dengan otak, tes subjektif berkaitan dengan kemampuan belajar menggunakan belahan otak kanan dan tes objektif berkaitan dengan kemampuan belajar menggunakan belahan otak kiri. Setiap peserta didik memiliki dominasi otak yang berbeda. Dengan adanya penelitian ini dapat membantu guru dalam memberi penanganan yang tepat kepada peserta didik sesuai dengan tipe peserta didik dalam menyelesaikan soal.

Materi yang diajarkan dalam penelitian ini yaitu gelombang bunyi dan cahaya dan alat optik. Data yang diperoleh berasal dari hasil belajar kemampuan kognitif. Masing-masing kelas sampel berjumlah 28 peserta didik yang terbagi dalam kelas XI IPA 6 sebagai kelas eksperimen dan kelas XI IPA 5 sebagai kelas kontrol.

Penelitian ini dilakukan secara tatap muka dan secara daring sehingga keterlibatan peserta didik dalam penelitian dapat diamati. Keterlibatan peserta didik dalam proses belajar dapat dilihat dengan memberikan bentuk tes yang berbeda. Kelas eksperimen yang dinilai tes objektif selama proses pembelajaran peserta didik cenderung diam dan kurang aktif dalam bertanya mengenai materi yang diajarkan, namun peserta didik cenderung menyimak secara seksama materi yang disampaikan oleh peneliti. Berbeda dengan kelas kontrol yang dinilai tes subjektif selama proses 
pembelajaran, peserta didik aktif dalam bertanya mengenai materi yang belum dipahami namun kurang menyimak pembelajaran yang disampaikan oleh peneliti.

Pembelajaran yang dilakukan secara daring memiliki kekurangan dan kelebihan dibandingkan pembelajaran tatap muka antara lain membuat interaksi peserta didik terhadap pengajar berkurang, kendala yang tidak terduga seperti jaringan internet yang tidak lancar, dan pemberian tes disetiap pertemuan beberapa peserta didik mempunyai cara penulisan jawaban yang sama. Proses penilaian pada tes objektif, peserta didik dapat melihat langsung jawaban yang benar dan salah ketika selesai mengerjakan tes sehingga dapat memberikan motivasi untuk mengerjakan ulang soal yang diberikan.

Hasil penelitian deskripftif menunjukkan bahwa hasil belajar fisika peserta didik kelas XI IPA SMA Negeri 1 Sidenreng Rappang pada kelas eksperimen yang dinilai menggunakan tes objektif selama pembelajaran memperoleh hasil belajar dalam kategori tinggi dan pada kelas kontrol yang dinilai menggunakan tes subjektif selama pembelajaran memperoleh hasil belajar dalam kategori tinggi.

Kelas eksperimen mempunyai rata-rata dalam mengerjakan soal pilihan ganda 15,5 dari rata-rata 25 dan soal essai 13,4 dari rata-rata 25. Kelas eksperimen cenderung menyelesaikan soal dalam bentuk tes pilihan ganda sementara untuk tes essai tidak semua peserta didik mengerjakan secara tuntas. Rata-rata hasil belajar secara keseluruhan diperoleh 28, 89 dari skor maksimum 50.

Kelas kontrol mempunyai rata-rata dalam mengerjakan soal pilihan ganda 14,1 dari rata-rata 25 dan soal essai 17,8 dari rata-rata 25 . Kelas kontrol secara umum menyelesaikan soal essai. Ratarata hasil belajar secara keseluruhan diperoleh 31, 92 dari skor maksimum 50.

Hasil penelitian yang dilakukan oleh peneliti menunjukkan bahwa rata-rata hasil belajar peserta didik yang dinilai dengan menggunakan tes subjektif lebih tinggi daripada tes objektif. Selain itu, secara umum peserta didik pada kelas kontrol menyelesaikan tes subjektif dengan nilai yang tinggi sementara kelas eksperimen beberapa peserta didik tidak mengerjakan soal dalam bentuk tes subjektif secara tuntas. Begitupun sebaliknya, peserta didik pada kelas eksperimen secara umum menyelesaikan tes objektif dengan nilai yang tinggi jika dibandingkan dengan kelas kontrol. Kedua kelas cenderung menyelesaikan bentuk soal yang diberikan selama proses pembelajaran karena sudah terbiasa dengan jawaban yang biasa disediakan sehingga diperoleh hasil yang berbeda.

Hasil pengujian normalitas dengan menggunakan persamaan Chi Kuadrat menunjukkan bahwa untuk hasil belajar fisika diperoleh $\chi_{\mathrm{h}}{ }^{2}=5,8987<\chi_{\mathrm{t}_{\mathrm{i}}}{ }^{2}=9,4877$ pada kelas eksperimen sedangkan kelas kontrol diperoleh nilai $\chi_{\mathrm{h}} \quad{ }_{\mathrm{g}}^{2}=7,8537<\chi_{\mathrm{t}_{\mathrm{i}}} \quad{ }^{2}=9,4877$. Hal ini menunjukkan bahwa populasi peserta didik dari kedua kelas terdistribusi normal dengan taraf signifikansi 0,05 .

Perhitungan pengujian homogenitas varians populasi untuk hasil belajar fisika diperoleh diperoleh $\mathrm{F}_{\mathrm{h}} \quad=1,224$ dan $\mathrm{F}_{\mathrm{t}_{\mathrm{i}}} \quad=1,905$. Karena $\mathrm{F}_{\mathrm{h}} \quad<\mathrm{F}_{\mathrm{t}_{\mathrm{i}}} \quad$ maka dapat disimpulkan bahwa data skor hasil belajar pada kedua kelas berasal dari populasi yang homogen. 
Hasil pengujian hipotesis diperoleh $t_{\text {hit }}=-1,076$ sedangkan $t_{t}=2,006$ pada taraf signifikan $0,05 \mathrm{dan} \mathrm{dk}=54$. Berdasarkan analisis tersebut dapat dilihat bahwa nilai $t_{\text {hit }}$ untuk hasil belajar fisika berada pada rentang $-2,006 \leq-1,076 \leq+2,006$. dengan demikian $H_{0}$ diterima dan $H_{1}$ ditolak, berarti dalam penelitian ini tidak terdapat perbedaan yang signifikan hasil belajar fisika peserta didik yang dinilai dengan menggunakan tes objektif dan tes subjektif.

Hal ini dikarenakan rerata skor kelompok peserta didik yang dinilai dengan menggunakan tes objektif 28,89 sedangkan kelompok peserta didik yang dinilai dengan menggunakan tes subjektif 31,92 dengan selisih rata-rata 3,03 yang berarti rata-rata kedua kelompok tidak berbeda secara signifikan. Meskipun hasil belajar yang diperoleh oleh peserta didik yang dinilai dengan menggunakan tes subjektif lebih tinggi daripada hasil belajar yang diperoleh oleh peserta didik yang dinilai dengan menggunakan tes objektif, akan tetapi secara statistik menyatakan bahwa tidak adanya perbedaan hasil belajar antara kedua kelas sampel. Dengan demikian ketika diberikan tes kepada peserta didik, baik menggunakan bentuk tes objektif maupun tes subjektif akan menghasilkan hasil yang sama.

Hal tersebut senada dengan hasil penelitian yang dilakukan oleh Murti, Wiyanto dan Hartono (2018) menunjukkan bahwa tidak ada perbedaan hasil belajar kognitif siswa antara yang dievaluasi dengan menggunakan tes bentuk teslet dan tes bentuk uraian. Selain itu, hasil penelitian yang dilakukan oleh Khan dan Badr (2011) serta Saeed (2017) menunjukkan bahwa tidak ada perbedaan signifikan tingkat keberhasilan yang dinilai dengan menggunakan soal pilihan ganda dan juga soal essai.

Persamaan penelitian di atas dengan penelitian yang dilakukan oleh peneliti yakni tidak ada perbedaan signifikan antara pemberian soal pilihan ganda dan essai. Namun yang berbeda adalah soal bentuk pilihan ganda lebih efektif dibandingkan dengan tes uraian. Sementara hasil yang diperoleh oleh peneliti yaitu peserta didik yang dinilai dengan menggunakan tes uraian memperoleh nilai lebih tinggi dibandingkan dengan tes pilihan ganda.

Hasil yang diperoleh menunjukkan bahwa bentuk soal yang diterapkan oleh guru selama ini ternyata memperoleh nilai hasil belajar yang lebih tinggi. Adapun yang menyebabkan hasil belajar fisika peserta didik yang dinilai menggunakan tes uraian lebih tinggi dibandingkan dengan bentuk soal pilihan ganda dikarenakan oleh faktor kebiasaan yang telah lama diterapkan oleh guru pada peserta didik sebelumnya.

Keterbatasan dalam penelitian ini yakni beberapa peserta didik tidak melaksanakan ujian secara serentak yang disebabkan oleh beberapa peserta didik sulit untuk login sehingga mempunyai waktu yang terbatas dalam mengerjakan tes. Selain itu, pelaksanaan ujian yang dilakukan secara daring peserta didik mempunyai peluang untuk bekerja sama dan mengakses internet serta buku. Namun untuk meminimalisir terjadinya kerjasama dalam menjawab soal maka butir soal diacak dan 
mengatur waktu pengerjaan soal, jika waktu yang telah ditentukan telah habis maka sistem akan log out secara otomatis.

\section{SIMPULAN}

Berdasarkan hasil penelitian dapat disimpulkan sebagai berikut.

1. Hasil belajar fisika peserta didik kelas XI IPA SMA Negeri 1 Sidenreng Rappang tahun 2019/2020 yang dinilai menggunakan tes objektif berada dalam kategori tinggi.

2. Hasil belajar fisika peserta didik kelas XI IPA SMA Negeri 1 Sidenreng Rappang 2019/2020 yang dinilai menggunakan tes subjektif dalam kategori tinggi.

3. Tidak terdapat perbedaan hasil belajar fisika peserta didik kelas XI IPA SMA Negeri 1 Sidenreng Rappang 2019/2020 yang dinilai menggunakan tes objektif dengan yang dinilai menggunakan tes subjektif

\section{DAFTAR RUJUKAN}

Ali, sidin dan Khaeruddin. 2012. Evaluasi pembelajaran. Makassar: Badan Penerbit Universitas Negeri Makassar

Arikunto, Suharsimi. 2009. Dasar-dasar Evaluasi Pendidikan (Edisi Revisi) . Jakarta: PT Bumi Aksara.

Bastable, Susan.B. 2002. Perawat sebagai Pendidik: Prinsip-Prinsip Pengajaran dan Pembelajaran. Jakarta: Kedokteran EGC.

Basuki, ismet dan Hariyanto. 2014. Asesmen Pembelajaran. Bandung: PT Remaja Rosdakarya.

Hamalik, Oemar. 2001. Proses Belajar Mengajar. Bandung: PT Bumi Aksara.

Khan, Moeen Uz Zafar dan Badr Muhammad Aljarllah. 2011. Evaluation of Modified Essay Questions (MEQ) and Multiple Choice Questions (MCQ) as a tool for Assessing the Cognitive Skills of Undergraduate Medical Students. International Journal of Health Sciences, Qassim University. Vol 5(1) : $39-43$.

Kusaeri. 2014. Acuan dan Teknik Penilaian Proses dan Hasil Belajar Kurikulum 2013. Yogyakarta: Ar-Ruzz Media.

Muhammad, As'Adi. 2010. Bila Otak Kanan dan Otak Kiri Seimbang. Jogjakarta: Diva Pess.

Murti, Wiyanto dan Hartono. 2018. Studi Komparasi antara Tes Testlet dan Uraian dalam Mengukur Hasil Belajar Kognitif Siswa Kelas XI SMA Negeri 1 Gombong. Unnes Physisc Educatioan Jounal. ISSN: 2252-6935

Riduwan. 2010. Metode dan Teknik Menyusun Tesis. Bandung: Alfabeta.

Rusman. 2015. Pembelajaran Tematik Terpadu. Bandung: PT Rajagrafindo Persada.

Saeed, Ghassan Th et al. 2017. Multiple Choice Questions And Essay Questions In Assessment Of Success Rate In Medical Physiology. Journal Of The Faculty Of Medicine Baghdad. Vol 59 No. 4.

Sudjana. 2005. Metoda Statistika. Bandung: PT. Tarsito Bandung.

Sugiyono. 2017. Metode Penelitian Kuantitatif, Kualitatif dan R\&D. Bandung: Alfabeta.

Susetyo, Budi. 2015. Prosedur Penyusunan \& Analisis Tes. Bandung: PT Refika Aditama.

Uno, Hamzah B dan Satria Koni. 2012. Assessment Pembelajaran. Jakarta: PT Bumi Aksara. 
Yusuf, A.Muri. 2015. Asesmen dan Evaluasi Pendidikan Pilar Penyedia Informasi dan Kegiatan Pengendali Mutu Pendidikan. Jakarta: Prenadamedia Group.

Zulaiha, Rahmah. 2008. Analisis Soal Secara Manual. Departemen Pendidikan Nasional Badan Penelitian dan Pengembangan Pusat Penilaian Pendidikan. Jakarta: PUSPENDIK. 